\title{
Os caminhos do ABO
}

\section{The paths of the $A B O$}

RuBENS BELFORT JR. ${ }^{1}$

\section{Prezado Editor,}

Por acreditar que nenhum "ex" deve continuar influindo em organizações após o término do seu mandato, até agora fiz questão de não participar dos Arquivos Brasileiros de Oftalmologia, desde que deixei a sua editoria científica, há mais de 10 anos. Afinal, qualquer "ex" deve tomar muito cuidado para não tentar manter o passado no presente e complicar o futuro, cerceando novas gerações. Esta é a conduta em praticamente todas as instituições desde a Presidência da República até outras bem menores.

Mas, depois desses anos todos, julgo-me no direito de escrever esta carta para comentar alguns aspectos relacionados aos Arquivos Brasileiros de Oftalmologia que são elogiosas à editoria atual e também à anterior, tão bem liderada pelo Harley Bicas.

No Congresso Internacional de Imunologia Ocular, em novembro passado, na Índia, ao discutirem Doenças Infecciosas e Imunopatologia várias vezes $0 \mathrm{ABO}$, e artigos nele publicados, foram citados elogiosamente.

Não teria acontecido se os artigos não fossem bons, o $A B O$ não estivessem indexados em praticamente todos os sistemas, incluindo PubMed. Mais importante ainda, esses artigos eviden- temente seriam mundialmente desconhecidos se não estivessem em inglês.

O ABO está no caminho correto e já tem o seu material disponível e acessível ao mundo todo. É importante continuar publicando em inglês, principalmente artigos de excelente conteúdo, para ser líder e participar do primeiro mundo.

Cada vez mais o papel dos revisores e de todos os editores científicos é crucial para a manutenção do bom nível da publicação. É papel dessa equipe garantir que todos os artigos sejam resumidos, economizando-se o tempo de quem escreve, revisa e lê. Verifica-se que mesmo artigos de revisão podem ser curtos, abrangendo apenas os pontos importantes. Trata-se de publicar sim e de maneira objetiva o que é novo e pode ser útil para informar os outros e educar, mudando o comportamento clínico-cirúrgico ou mesmo o pensamento.

$\mathrm{O}$ ABO continua a contar em seu conselho editorial com excelentes oftalmologistas-cientistas e todos nós devemos muito a eles pelo seu importante, difícil, não remunerado e quase anônimo trabalho.

Cordialmente,

Rubens

Submitted for publication: December 27, 2011

Accepted for publication: January 9, 2012

Professor, Departamento de Oftalmologia, Universidade Federal de São Paulo - UNIFESP - São Paulo (SP), Brazil.
Funding: No specific financial support was available for this study.

Disclosure of potential conflicts of interest: R.Belfort Jr., None.

Correspondence address: Rubens Belfort Jr. Rua Dr. Diogo de Faria, 1036 - 4aandar - São Paulo (SP) - 04037-003 - Brazil

E-mail: iara@oftalmo.epm.br 